\title{
Modified U-Cell Inverter using Advanced Process Controller for Photovoltaic Applications
}

\author{
Sumathi R, Sankari V
}

\begin{abstract}
This paper proposes a single phase modified seven level $U$-Cell inverter configurations in which the advanced process controller has been implemented. By using the boost operation the output of the inverter will produce higher output voltage when compared to the maximum DC source value used. To obtain maximum power the designed inverter is implemented with the photovoltaic system where the power is produced from two different PV panels which is connected to DC link by using DC-DC converters. The semiconductor switches and DC links are used to generate the inverter AC output voltages with seven levels. Two PV panels with different voltages are used in which two panels voltages are combined and their powers are injected to the grid. To validate the dynamic performance of the proposed $U$-Cell inverter the advanced process controller is used in the inverter connected to the grid. The controller is designed and processed to maintain the capacitor voltage to obtain the desired AC output with desired magnitude. The dynamic performance during changes in the supply current and DC voltage of capacitor for the process controller has been obtained.
\end{abstract}

Keywords: Advanced process controller, modified U-Cell inverter, $P V$ panels, $U$-Cell inverter.

\section{INTRODUCTION}

Power electronics inverters are exceptionally deprived as interface to convey capacity to the grid and loads. Diminishing the natural contamination by expanding the productivity and diminishing power losses. Since the quantity of purchasers has been expanded and the quantity of high force ventures is expanded force network has surprisingly confronted higher vitality request [1]. Because of the improving innovation of semiconductor gadgets the Power electronic equipment is supplanting massive transformers. Much research has been centered essentially around staggered inverter advancement considering both the topology and control procedure angles. The primary consideration is paid to the quantity of segments utilized in such sorts of inverters. Power inverters are generally utilized in sustainable power source transformation frameworks to

Revised Manuscript Received on February 05, 2020.

* Correspondence Author

R. Sumathi*, Department of Electrical and Electronics Engineering, Sri Krishna College of Engineering and Technology, Coimbatore, India. Email: sumathir@skcet.ac.in

V.Sankari, Department of Electrical and Electronics Engineering, Sri Krishna College of Engineering and Technology, Coimbatore, India. Email: 18eppe002@skcet.ac.in

(C) The Authors. Published by Blue Eyes Intelligence Engineering and Sciences Publication (BEIESP). This is an open access article under the CC BY-NC-ND license (http://creativecommons.org/licenses/by-nc-nd/4.0/) convey green capacity to the clients. Monetary expenses of intensity switches make them gainful to produce and permit them to contend in the market [2]. These days, utilizing more switches in the inverter structure doesn't build the cost fundamentally, hence, two-level ordinary converters with high power losses and harmonics substance are being supplanted by low exchanging recurrence staggered inverters quickly.

Regular inverters have a few downsides like non sinusoidal yield voltage wealthy in Total harmonic distortion (THD), high switching losses and thermal stress at high exchanging recurrence with significant level of basic mode commotion [3]-[6]. Staggered inverters establish a class of gadgets which present intriguing highlights that are normally adjusted to sun powered vitality change plans and in this way comprise a fascinating answer for the sun oriented vitality innovation. Customary staggered inverters present produce numerous disadvantages they are exorbitant and difficult to actualize when the quantity of voltage levels increments. So as to beat the effect of such issues, new staggered inverters topologies have been proposed. On the off chance that the quantity of parts utilized is less, the power losses will be less and the cost will likewise be less [7]. The seven-level MUC inverter has been created and proposed for applications with significant focal points like actualizing low number of segments moreover it additionally produces more elevated levels of AC voltages at the yield.

The created structure has lower number switches than the seven-level CHB inverter which likewise shows a similar exhibition of the inverter. Right now of the inverter, two diverse DC sources which is gotten by the two distinctive PV boards are utilized to produce the seven degrees of AC voltages with low sounds and appropriate voltage sharing between the levels. The yield AC voltage acquired would have higher greatest incentive as entirety of the two DC sources amplitudes, which can be gotten with the assistance of a boost operation and solution for the low voltage utilization of the referenced U-Cell inverter. In spite of the fact that best in class process controller was created are straightforward and instinctive. Contrasting propelled process controller with other old style controllers, countless figuring ought to be executed at each time step before imparting the suitable ideal sign to the gadgets. Process controller comprises of figuring the future conduct of the controlled factors, contrasting them with their references, ascertaining cost work which ought to be limited so as to pick the ideal state. 
Then again, it includes some intriguing qualities, for example, quick powerful reaction, precise following, and no increases to tune and no compelling reason to utilize an outside sort of modulators. Right now, process controller is produced for the MUC inverter for grid connected application.

\section{PROPOSED METHEDOLOGY}

In this methodology of the modified seven level U-Cell configuration, the difficulties occurred in the existing system has been solved and overcome by implementing the advanced process control technique. The major difficulties of the existing system are the dynamic response was poor and the system is unstable which has overcome by implementing this advanced controller in place of PI controller part which is mainly helpful to regulate the fixed output.

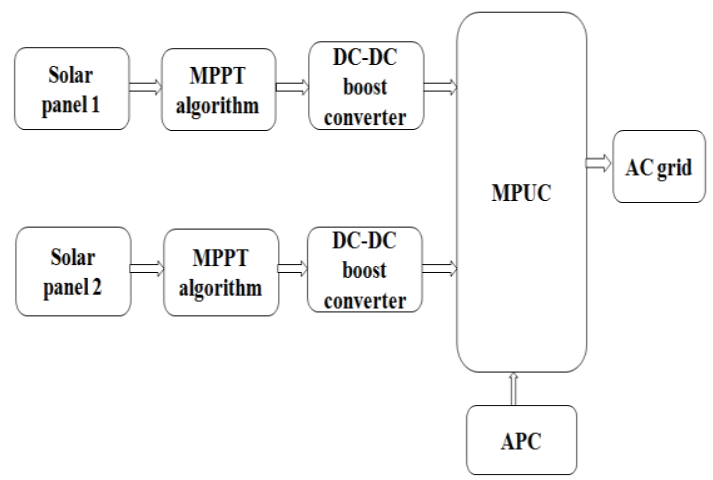

Fig 2.1. Block diagram of proposed inverter topology

In the field of conversion of renewable energy the main idea of the seven level U-Cell inverter application is where two different photovoltaic panels with two different voltages are connected to the inverter as the DC source. The sources are combined by connecting it with the boost converter which is controlled by the maximum power point algorithm. The two DC voltages obtained by two photovoltaic panels are summed up by the inverter to obtain required energy.

\section{MU-CELL INVERTER}

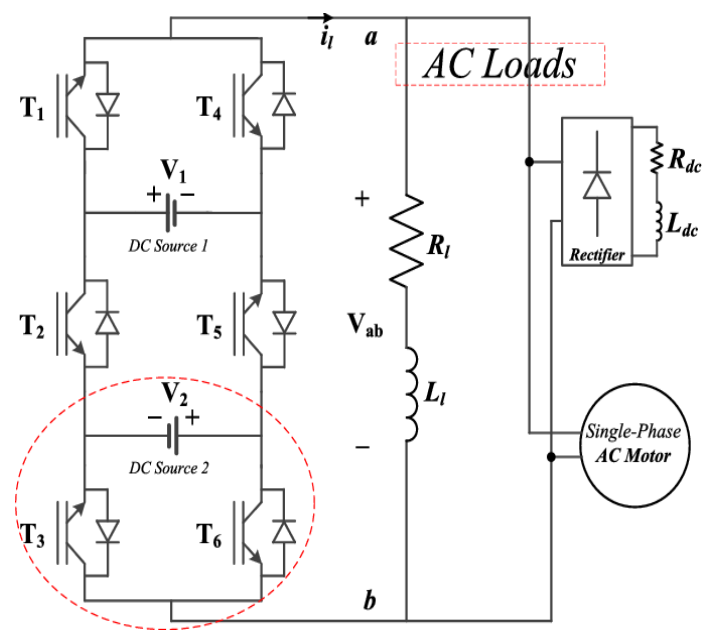

Fig 3.1. Seven level MU-Cell Inverter topology with Boost Operation

Because of ongoing advancement in solar panel and decreased costs, it is easy to utilize more Photo voltaic boards as DC sources. Subsequently, staggered inverters utilizing more DC sources are supported monetarily [7]-[9].
Consequently, a capacitor has been set in the U-Cell topology as the reliant second source and a few controllers [12] have been intended to keep the voltage (V2) consistent at the 33\% degree of the reference voltage (V1). The yield voltage waveform (Vab) and DC capacitor current got by simulation. The load incorporated a resistor of $100 \Omega$. It is evident from the yield voltage waveform (Vab) of the U-Cell inverter showed that the most extreme adequacy of the AC voltage is equivalent to the DC source amplitude.

Table-I: Switching state and output voltage levels generated by MUC

\begin{tabular}{cccccccc}
\hline \hline $\begin{array}{c}\text { Switching } \\
\text { State }\end{array}$ & $\mathbf{T}_{\mathbf{1}}$ & $\mathbf{T}_{\mathbf{2}}$ & $\mathbf{T}_{\mathbf{3}}$ & $\mathbf{T}_{\mathbf{4}}$ & $\mathbf{T}_{\mathbf{5}}$ & $\mathbf{T}_{\mathbf{6}}$ & $\mathbf{V}_{\mathbf{a b}}$ \\
1 & 1 & 0 & 1 & 0 & 1 & 0 & $\mathrm{~V}_{1}+\mathrm{V}_{2}$ \\
2 & 1 & 0 & 0 & 0 & 1 & 1 & $\mathrm{~V}_{1}$ \\
3 & 0 & 0 & 1 & 1 & 1 & 0 & $\mathrm{~V}_{2}$ \\
4 & 0 & 0 & 0 & 1 & 1 & 1 & 0 \\
5 & 1 & 1 & 1 & 0 & 0 & 0 & 0 \\
6 & 1 & 1 & 0 & 0 & 0 & 1 & $-\mathrm{V}_{2}$ \\
7 & 0 & 1 & 1 & 1 & 0 & 0 & $-\mathrm{V}_{1}$ \\
8 & 0 & 1 & 0 & 1 & 0 & 1 & $\mathrm{~V}_{2}+\mathrm{V}_{1}$ \\
\hline \hline
\end{tabular}

By considering the above table the switching state for seven-level of voltages has been implemented. The seven levels of voltage include two positive sequence of voltages, two negative sequence of voltages, two zero sequence of voltages and finally, two voltage sequence which can be neither positive nor negative [14]. This can be clearly validated using the above table.

\section{ADVANCED PROCESS CONTROL}

The advanced process control is used when satisfying a set of constraints to control a process. It has also been developed in recent years and is used in model balancing power systems and in power electronics [10]. This control method has been in use in chemical plants and refineries in the industries. The main advantage of the advanced process controller is that it allows optimization of the current time slot while keeping future time slots in mind.

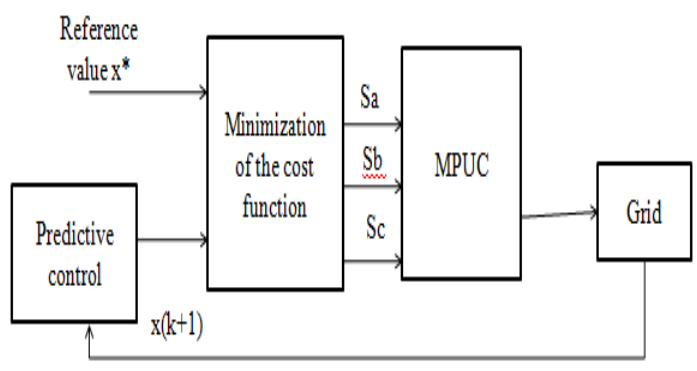

$x(k)$

Fig 4.1. General structure of MPC

The process controller regularly conveys just the primary change in every autonomous variable to be executed, and rehashes the estimation when the following change is required. While thinking about when numerous real processes are not linear, they can regularly be viewed as roughly straight over a little working extent [11], [13]. During those occurrences this would be useful.

Published By: 


\section{SIMULATION RESULTS AND DISCUSSION}

On the left side, two PV arrays with two unique ratings of voltages from two different producers are associated with the MUC inverter through DC/DC boost converters, which was worked by MPPT algorithm to acquire the most extreme power. The $\mathrm{P} \& \mathrm{O}$ algorithm is all around portrayed and is exhaustively utilized by the ventures. The MU-Cell inverter can convey sun powered vitality to the grid or loads.

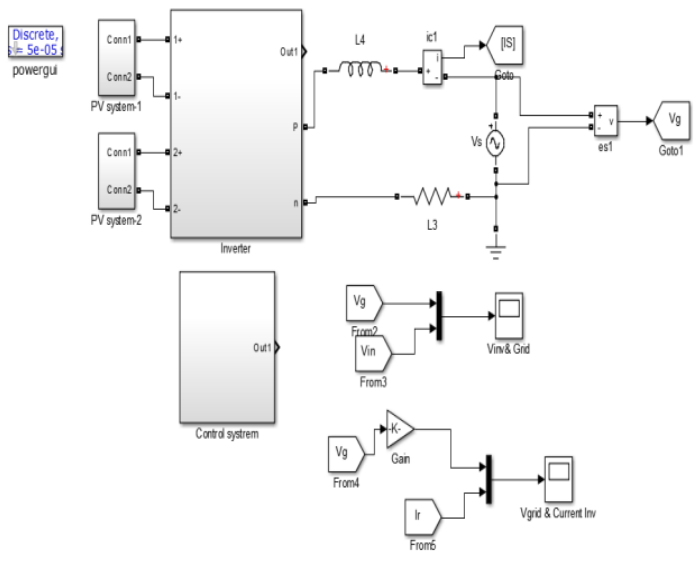

Fig 5.1. Overall Simulation of Proposed System

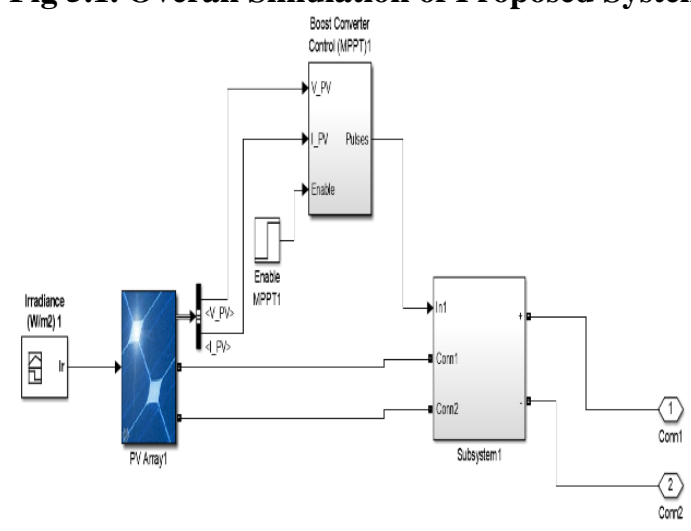

Fig 5.2. solar panel 1

The first PV array consists of sun power SPR-305-WHT panels are connected with boost converter and MPPT algorithm implemented.

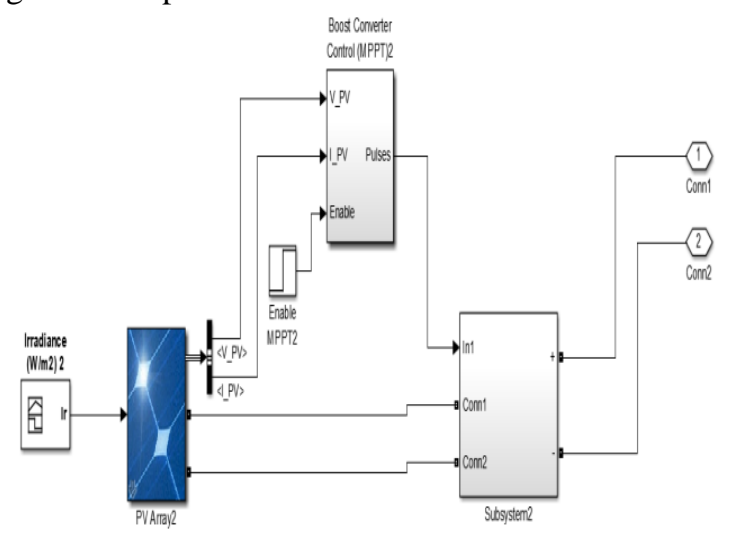

Fig 5.3. Solar panel 2

The second PV panel (BP solar SX3190) is connected with a boost converter with MPPT algorithm implemented.

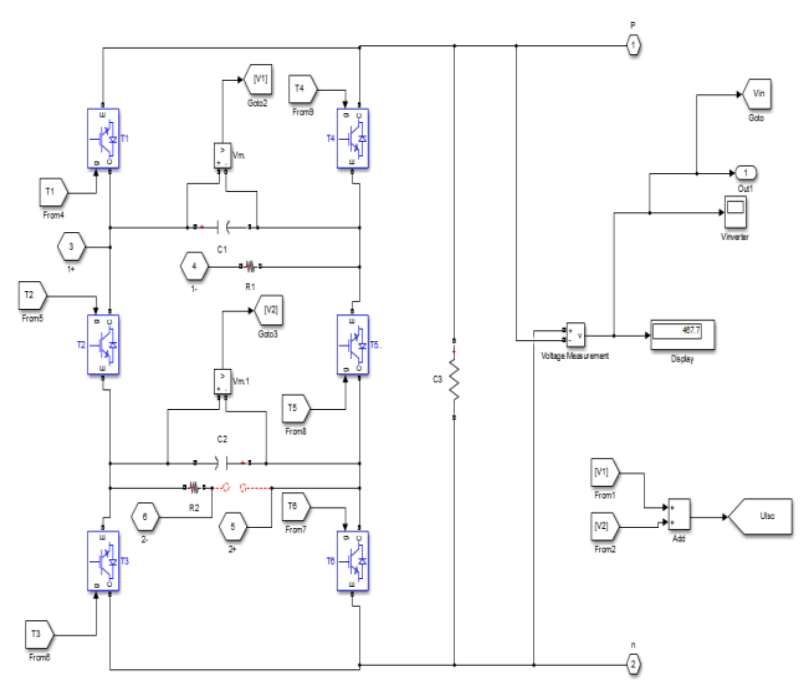

Fig 5.4. MUC Inverter

By using the switches with the help of gate pulses the flow of current can be blocked or conducted.

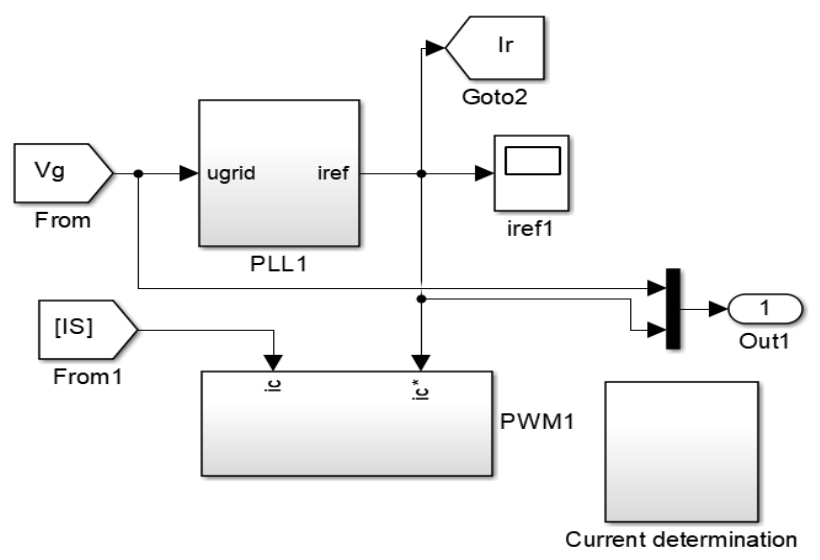

Fig 5.5. Control structure of proposed system

The above block represents the structure of the control structure actualized in the proposed system which is utilized during the time spent controlling power traveled to the AC network by synchronizing grid voltage and current waveforms just as managing DC capacitors voltages to have 7-level low THD voltage waveform.

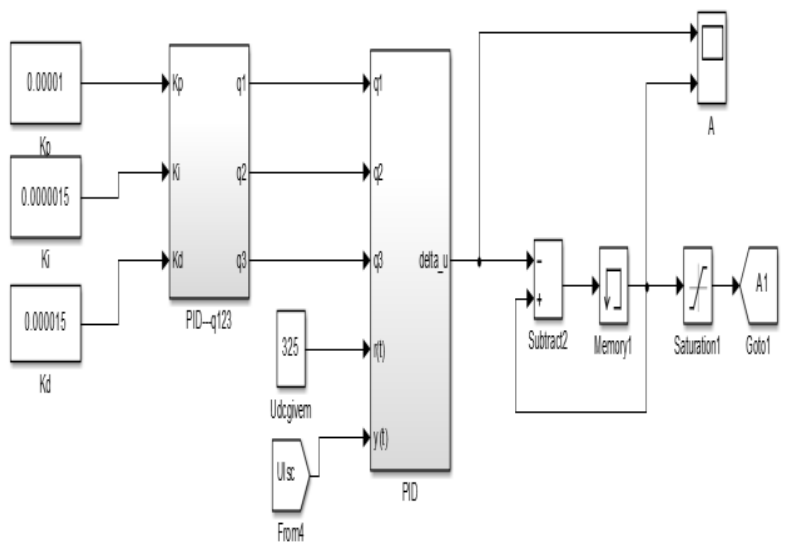

Fig 5.6. Current determination block 
The planned process controller has been actualized in the present assurance block so as to give the capacity of the inverter in conveying power from PV clusters to the network, a Matlab reproduction has been performed dependent on the structured controller.

\section{CONCLUSION}

In this paper, adjusted staggered inverter topology has been displayed. The proposed MU-Cell inverter can produce 7-level AC voltage waveform at the yield with low distortion. Not at all like the detailed U-Cell topology, is the 7-level MU-Cell inverter competent to deliver voltage levels more than the DC sources utilized in the structure. The DC sources can be summarized to convey more capacity to the output. The related switching algorithm known as cutting edge process controller has been planned and actualized on the presented MU-Cell topology with decreased switching frequency viewpoint. In addition, photovoltaic application has been focused for this inverter to convey power from two boards with various voltage and current rating to grid. In this, results have been appeared to approve the satisfactory voltage regulation and current controlling of the grid associated inverter furthermore with the executed $\mathrm{P} \& \mathrm{O}$ Maximum power point algorithm.

\section{REFERENCES}

1. I. Gowaid, G. Adam, A. Massoud, S. Ahmed, and B. Williams, "Hybrid and Modular Multilevel Converter Designs for Isolated HVDC-DC Converters," IEEE journal of Emerging and Selected Topics in Power Electronics, Vol. 6, No. 1, pp. 188-202, 2018.

2. M. Sharifzadeh, H. Vahedi, A. Sheikholeslami, P.-A. Labbé, and K. Al-Haddad, "Hybrid SHM-SHE Modulation Technique for Four-Leg NPC Inverter with DC Capacitors Self-Voltage-Balancing," IEEE Transactions on Industrial Electronics, Vol. 62, No. 8, pp. 4890-4899, 2015.

3. F. Sebaali, H. Vahedi, H. Y. Kanaan, N. Moubayed, and K. Al-Haddad, "Sliding Mode Fixed Frequency Current Controller Designed for GridConnected NPC Inverter," IEEE journal of Emerging and Selected Topics in Power Electronics, Vol. 4, no. 4, pp. 1397-1405, 2016.

4. M. Sharifzadeh, H. Vahedi, R. Portillo, M. Khenar, A. Sheikholeslami, L. G. Franquelo, et al., "Hybrid SHM-SHE Pulse Amplitude Modulation for High Power Four-Leg Inverter," IEEE Transactions on Industrial Electronics, Vol. 63, No. 11, pp. 7234-7242, 2016.

5. H. Nademi, A. Das, R. Burgos, and L. E. Norum, "A new circuit performance of modular multilevel inverter suitable for photovoltaic conversion plants," IEEE journal of Emerging and Selected Topics in Power Electronics, Vol. 4, No. 2, pp. 393-404, 2016.

6. H. Vahedi, P. Labbe, and K. Al-Haddad, "Sensor-Less Five-Level Packed U-Cell (PUC5) Inverter Operating in Stand-Alone and Grid Connected Modes," IEEE Transactions on Industrial Informatics, Vol. 12, No. 1, pp. 361- 370, 2016.

7. H. Vahedi and K. Al-Haddad, "Real-Time Implementation of a Seven Level Packed U-Cell Inverter with a Low-Switching-Frequency Voltage Regulator," IEEE Transactions on Power Electronics, Vol. 31, No. 8, pp. 5967-5973, 2016.

8. Y. Ounejjar, K. Al-Haddad, and L. A. Grégoire, "Packed U cells multilevel converter topology: theoretical study and experimental validation," IEEE Transactions on Industrial Electronics, Vol. 58, No. 4, pp. 1294-1306, 2011.

9. M. A. Elgendy, B. Zahawi, and D. J. Atkinson, "Assessment of perturb and observe MPPT algorithm implementation techniques for PV pumping applications," IEEE Transactions on Sustainable Energy, Vol. 3, No. 1, pp. 21-33, 2012.

10. M. A. G. De Brito, L. Galotto, L. P. Sampaio, G. de Azevedo e Melo, and C. A. Canesin, "Evaluation of the main MPPT techniques for photovoltaic applications," IEEE Transactions on Industrial Electronics, Vol. 60, No. 3, pp. 1156-1167, 2013.

11. H. Vahedi, K. Al-Haddad, Y. Ounejjar, and K. Addoweesh, "Crossover Switches Cell (CSC): A New Multilevel Inverter Topology with Maximum Voltage Levels and Minimum DC Sources," in IECON 2013-39th Annual Conference on IEEE Industrial Electronics Society, Austria, 2013, pp. 54-59.

12. R. Sumathi and P. Umasankar, "New opposition cuttlefish optimizer based two-step approach for optimal design of fractional order proportional integral derivative controller for time delay systems," International Journal of Numerical Modelling: Electronic Networks, Devices and Fields, pp: 1-26, 2019

13. S. Kouro, P. Cortés, R. Vargas, U. Ammann, and J. Rodríguez, "Model predictive control-A simple and powerful method to control power converters," IEEE Transactions on Industrial Electronics, Vol. 56, No. 6, pp. 1826-1838, 2009.

14. S. Vazquez, J. Leon, L. G. Franquelo, J. Rodriguez, H. Young, A. Marquez, and P. Zanchetta, "Model predictive control: A review of its applications in power electronics," IEEE Industrial Electronics Magazine, Vol. 8, No. 1, pp. 16-31, 2014.

\section{AUTHORS PROFILE}

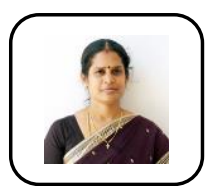

Dr. R. Sumathi received her BE degree in Electrical andElectronics Engineering from the Madras University, India, in 1998, the ME degree in Process control and Instrumentation from the Annamalai University, India, in 2004 and the $\mathrm{PhD}$ in the area of Control Theory from the Anna University Chennai, India, in 2015. She is currently working as an Associate Professor in the Department of Electrical and Electronics Engineering at Sri Krishna College of Engineering and Technology, Coimbatore, India. She has 17 years of teaching and research experience. She has been published 18 national and international journals. Her research interests include modelling and identification of control systems, learning control algorithms for robot manipulators and real time implementation of control systems.

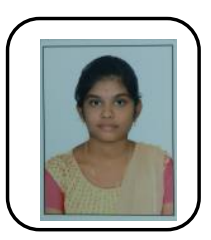

V.SANKARI received her BE degree in Electrical and Electronics Engineering from Anna University, Chennai, India, in 2017 and doing her ME degree in Power Electronics and Drives at Sri Krishna College of Engineering and Technology, Coimbatore, India. 